\title{
Pertussis in Florida
}

ROBERT M. THORNER, M.P.H., and JAMES O. BOND, M.D.

$\mathbf{P}$ ERTUSSIS killed more children than poliomyelitis in Florida in 1955, and three times as many cases of pertussis as of poliomyelitis were reported to the Florida State Board of Health. While remarkable advances have been made in the control of whooping cough, the disease continues to remind us that it is neither friendly nor familiar as we so often assume.

Physicians in private practice and public health have carried out an intensive campaign against pertussis in the past decade. Their major weapons have been active immunization with pertussis vaccine and antibiotic therapy of the clinical disease. Vaccine has been given to increasingly greater proportions of the child population since it was first introduced for general use in 1944. The antibiotic therapy of pertussis has been less effective than immunization in eradicating infection with Haemophilus pertussis itself $(1,2)$. However, the control of intercurrent infections has undoubtedly aided in preventing deaths and shortening periods of communicability. These efforts are to be equated with the results obtained from a review of the morbidity and mortality statistics on whooping cough accumulated by the Florida State Board of Health over a period of almost 40 years.

\section{Time Trends in Whooping Cough}

The trend of reported whooping cough case rates for the entire history of case reporting in Florida is presented in table 1 and the chart. Whooping cough has been considerably underreported at all times. Though it is possible that reporting has improved some during the period covered, the extent of any such improve- ment is unknown. It is certain that the case rates understate the magnitude of the pertussis problem, but they are undoubtedly a valid indication of the trend of the disease.

Over the years there is considerable fluctuation of the rates, with epidemics occurring at intervals of 4 to 6 years, but 2 distinct almost level trends are distinguishable. One extends from 1918 to 1948 , with a mean annual rate of 38.7 per 100,000 population. The other extends from 1948 to 1955 , with a mean annual rate of 16.8 or a decline of 56.6 percent. This drop may be the result of treatment of the disease in the early stages with antibiotics, resulting in control without diagnosis and reporting, or it may be related to the introduction and use of pertussis vaccine.

In contrast to the morbidity rates, the death rate from whooping cough shows a declining trend over the entire period from 1918 to 1955 (table 1). The reason for this in view of the unchanging case rate is not apparent. It does not appear to be related through time to the introduction of either new preventive or therapeutic techniques.

\section{Infant Death Rate}

Cases and deaths by age for the 5 -year period 1951-55 are presented in tables 2 and 3 . Of the reported cases with stated age for this period, $\mathbf{1 7 . 9}$ percent were in infants under 1 year of age (table 2). Among the fatalities, 73.5 percent were less than 1 year old (table 3 ). The deaths that occurred within the first year of

Mr. Thorner is a statistician and Dr. Bond an epidemiologist with the Florida State Board of Health, Jacksonville. 
life are, however, fairly evenly distributed by age in months with the exception of the neonatal period when no deaths were recorded.

It has been a general policy in Florida to begin the course of immunizing injections at 3 to 6 months of age. It is of interest to note that 36.7 percent of the deaths occurred in children under 6 months of age and 18.4 percent in those under 3 months of age.

Although cases and deaths from whooping cough occur in both white and nonwhite persons, there is a definite concentration of the cases among the nonwhites (table 4). Over the 5-year period 1951-55 the rates for non-

Table 1. Reported cases and deaths from whooping cough, rates, and case fatality ratios, Florida, 1918-55

\begin{tabular}{|c|c|c|c|c|c|}
\hline \multirow{2}{*}{ Year } & \multirow{2}{*}{$\begin{array}{c}\text { Number of } \\
\text { cases }\end{array}$} & \multirow{2}{*}{$\begin{array}{l}\text { Number of } \\
\text { deaths }\end{array}$} & \multicolumn{2}{|c|}{$\begin{array}{c}\text { Rates per } 100,000 \text { popu- } \\
\text { lation }\end{array}$} & \multirow{2}{*}{$\begin{array}{c}\text { Case } \\
\text { fatality } \\
\text { ratio } i\end{array}$} \\
\hline & & & Cases & Deaths & \\
\hline 1918 & 557 & 151 & 59.6 & 16. 1 & 27. 1 \\
\hline $1919 \ldots \ldots \ldots \ldots$ & 203 & 51 & 21. 2 & 5. 3 & 25. 1 \\
\hline $1920 \ldots \ldots \ldots \ldots \ldots \ldots \ldots$ & 347 & 64 & 34. 9 & 6. 4 & 18. 4 \\
\hline $1921 \ldots \ldots \ldots \ldots \ldots \ldots \ldots \ldots$ & 333 & 68 & 32. 0 & 6. 5 & 20. 4 \\
\hline $1922 \ldots \ldots \ldots \ldots \ldots \ldots \ldots \ldots$ & 94 & 30 & 8. 6 & 3.1 & 31. 9 \\
\hline 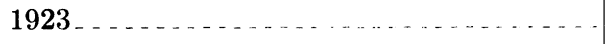 & 410 & 71 & 36. 0 & 6. 2 & 17. 3 \\
\hline $1924 \ldots$ & 444 & 111 & 37. 4 & 9.3 & 25. 0 \\
\hline $1925 \ldots \ldots \ldots \ldots \ldots \ldots \ldots$ & 493 & 66 & 39. 9 & 5. 3 & 13. 4 \\
\hline $1926 \ldots$ & 748 & 55 & 58. 2 & 4. 3 & 7. 4 \\
\hline $1927 \ldots$ & 654 & 67 & 49.0 & 5. 0 & 10. 2 \\
\hline $1928 \ldots \ldots \ldots \ldots$ & 321 & 43 & 23. 2 & 3. 1 & 13. 4 \\
\hline 1929 & 1,171 & 86 & 81.8 & 6. 0 & 7. 3 \\
\hline 1930 & 398 & 56 & 26. 9 & 3. 8 & 14. 1 \\
\hline $1931 \ldots$ & 420 & 25 & 27. 9 & 1. 7 & 6. 0 \\
\hline $1932 \ldots \ldots \ldots \ldots$ & 379 & 31 & 24. 8 & 2. 0 & 8. 2 \\
\hline 1933 & 508 & 44 & 32. 7 & 2. 8 & 8. 7 \\
\hline $1934 \ldots \ldots \ldots \ldots \ldots \ldots$ & 723 & 109 & 45. 6 & 6. 9 & 15. 1 \\
\hline $1935 \ldots$ & 532 & 59 & 32.8 & 3.6 & 11. 1 \\
\hline 1936 & 373 & 25 & 22.2 & 1. 5 & 6. 7 \\
\hline $1937 \ldots \ldots \ldots \ldots \ldots$ & 540 & 58 & 31.1 & 3. 3 & 10. 7 \\
\hline $1938 \ldots$ & 876 & 68 & 48. 9 & 3. 8 & 7.8 \\
\hline 1939 & 1,124 & 60 & 60. 6 & 3. 2 & 5. 3 \\
\hline 1940 & 383 & 39 & 20.0 & 2. 0 & 10. 2 \\
\hline $1941 \ldots \ldots \ldots \ldots$ & 747 & 36 & 37. 6 & 1. 8 & 4. 8 \\
\hline $1942 \ldots \ldots \ldots \ldots$ & 828 & 47 & 40. 3 & 2. 3 & 5. 7 \\
\hline $1943_{-} \ldots \ldots \ldots \ldots \ldots$ & 1,134 & 72 & 53.3 & 3. 4 & 6. 3 \\
\hline 1944 & 981 & 48 & 44. 7 & 2. 2 & 4. 9 \\
\hline 1945 & 477 & 29 & 21. 0 & 1. 3 & 6. 1 \\
\hline $1946 \ldots \ldots \ldots \ldots \ldots \ldots$ & 1,029 & 12 & 43. 3 & .5 & 1. 2 \\
\hline $1947 \ldots$ & 1,861 & 30 & 74. 9 & 1. 2 & 1. 6 \\
\hline $1948 \ldots \ldots \ldots \ldots \ldots \ldots \ldots$ & 731 & 21 & 28. 2 & .8 & 2. 9 \\
\hline $1949 \ldots \ldots \ldots \ldots$ & 191 & 6 & 7. 1 & .2 & 3. 1 \\
\hline $1950 \ldots$ & 471 & 8 & 16. 8 & .3 & 1. 7 \\
\hline $1951 \ldots$ & 920 & 27 & 31.7 & .9 & 2. 9 \\
\hline $1952 \ldots \ldots \ldots \ldots$ & 291 & 5 & 9. 7 & .2 & 1. 7 \\
\hline $1953 \ldots \ldots \ldots \ldots \ldots \ldots$ & 209 & 4 & 6. 7 & .1 & 1. 9 \\
\hline 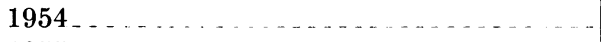 & 339 & 1 & 9. 7 & $\left({ }^{2}\right)$ & .3 \\
\hline $1955 \ldots \ldots \ldots \ldots \ldots$ & 1,080 & 12 & 29. 6 & .3 & 1. 1 \\
\hline
\end{tabular}

1 Deaths per 100 cases.

2 Rate less than 0.1 . 
Reported case rates of whooping cough, Florida, 1918-55

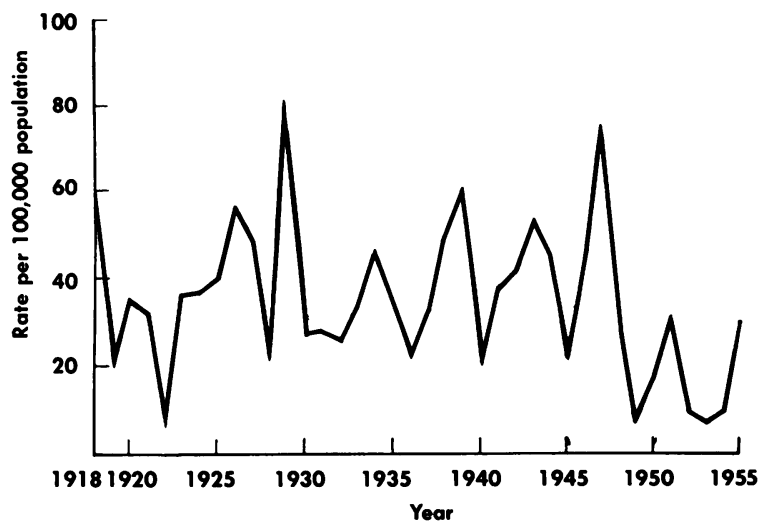

white persons averaged 22.3 compared with 17.0 for white persons. The mortality rate for nonwhites was 1.2 per 100,000 compared with 0.1 for whites, or 12 times as great. This difference is statistically significant at the 5 percent level.

\section{The Epidemic Year 1955}

In 1955, Florida experienced a sharp rise in the incidence of whooping cough (see chart). This increase was not wholly unexpected since, as has been previously noted, such peaks of incidence have tended to occur at intervals of 4 to 6 years. Nevertheless, a special surveillance of whooping cough cases and deaths was carried out to discover if the rise was due to true whooping cough and to elicit information which might aid in the prevention of future epidemics.

An epidemiological investigation was attempted for each of the 13 deaths occurring in 1955 and reported as due to whooping cough. Final evaluation of the information obtained verified that 9 of these deaths were due to whooping cough; 1 was definitely not whooping cough; and in the remaining 3 the information was insufficient to warrant any conclusions.

Of the 12 definite or probable whooping cough deaths, 11 were in Negroes and 1 in a white child. Eight were under 1 year of age, and 6 of these were 6 months of age or younger. There was a disturbingly consistent clinical pattern in the nine cases with reasonably complete information. The usual onset was insidious and did not arouse the concern of parents or physician, if the latter was consulted. There followed 2 or 3 weeks of progressively more severe coughing, accompanied by unsuccessful attempts to treat with home remedies or refills of original prescriptions. Characteristic, severe paroxysmal coughing with exsufflation of air and inspiratory whoop was often not present until the final week of the illness. The child usually appeared for medical attention either in extremis or with irreversible damage from anoxia and dehydration. Of the 5 patients taken to hospitals, 4 died within 48 hours of admission, and 1 died en route. In only 3 of the patients were $\mathrm{X}$-rays taken; 3 had routine blood counts at some time during their illness, and in none were cultures of the nose and throat obtained.

The equivocal beneficial effect of antibiotic therapy of pertussis was emphasized by the list of seven antibiotics received by these children as a group. In only one child was pertussis hyperimmune serum used for therapy. It would be inaccurate, however, to describe these as treatment failures, since in no case did the physician have the opportunity to institute

Table 2. Reported cases of whooping cough, by age in years, Florida, 1951-55

\begin{tabular}{|c|c|c|c|c|c|c|c|c|c|}
\hline Year & All ages & Under 1 & 1 & 2 & 3 & 4 & $5-9$ & $\begin{array}{l}10 \text { and } \\
\text { over }\end{array}$ & $\begin{array}{c}\text { Age not } \\
\text { stated }\end{array}$ \\
\hline $\begin{array}{l}1951 \ldots 1 \\
1952 \\
1953 \\
1954 \\
1955\end{array}$ & $\begin{array}{r}920 \\
291 \\
209 \\
339 \\
1,080\end{array}$ & $\begin{array}{r}137 \\
52 \\
41 \\
56 \\
201\end{array}$ & $\begin{array}{r}79 \\
33 \\
32 \\
29 \\
127\end{array}$ & $\begin{array}{r}92 \\
33 \\
25 \\
41 \\
103\end{array}$ & $\begin{array}{l}96 \\
39 \\
17 \\
34 \\
88\end{array}$ & $\begin{array}{r}74 \\
22 \\
8 \\
29 \\
84\end{array}$ & $\begin{array}{r}335 \\
76 \\
66 \\
99 \\
292\end{array}$ & $\begin{array}{r}85 \\
24 \\
16 \\
24 \\
131\end{array}$ & $\begin{array}{r}22 \\
12 \\
4 \\
27 \\
54\end{array}$ \\
\hline Total & 2,839 & 487 & 300 & 294 & 274 & 217 & 868 & 280 & 119 \\
\hline Cumulative percent ${ }^{1} \ldots$ & 100. 0 & 17. 9 & 28. 9 & 39. 7 & 49. 8 & 57. 8 & 89. 7 & 100. 0 & \\
\hline
\end{tabular}

${ }^{1}$ Unknown ages excluded. 
Table 3. Deaths from whooping cough, by age, Florida residents, 1951-55

\begin{tabular}{|c|c|c|c|c|c|c|c|c|c|c|c|c|c|c|}
\hline \multirow{2}{*}{ Year } & \multirow{2}{*}{$\begin{array}{c}\text { All } \\
\text { ages }\end{array}$} & \multirow{2}{*}{$\begin{array}{c}\text { Under } \\
28 \\
\text { days }\end{array}$} & \multirow{2}{*}{$\begin{array}{c}28-59 \\
\text { days }\end{array}$} & \multicolumn{10}{|c|}{ Months } & \multirow{2}{*}{$\begin{array}{c}\text { Over } \\
1 \\
\text { year }\end{array}$} \\
\hline & & & & 2 & 3 & 4 & 5 & 6 & 7 & 8 & 9 & 10 & 11 & \\
\hline $\begin{array}{l}1951 \ldots \\
1952 \ldots 5 \\
1953 \ldots 54 \\
1955 \ldots \ldots\end{array}$ & \begin{tabular}{r|}
27 \\
5 \\
4 \\
1 \\
12
\end{tabular} & 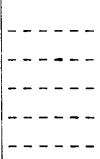 & $\begin{array}{r}4 \\
-\cdots--- \\
-\cdots- \\
-\cdots\end{array}$ & $\begin{array}{r}2 \\
1 \\
-\cdots- \\
---\overline{1}\end{array}$ & $\left|\begin{array}{r}2 \\
---\frac{1}{1} \\
---\frac{1}{1}\end{array}\right|$ & $\mid \begin{array}{r}1 \\
1 \\
\cdots-. \\
-\cdots \\
-\cdots\end{array}$ & $\begin{array}{r}1 \\
--- \\
-\cdots \\
1\end{array}$ & $\begin{array}{r}1 \\
1 \\
-\cdots-1 \\
-\cdots\end{array}$ & $\begin{array}{r}3 \\
\cdots \\
\cdots \\
\cdots \\
\cdots \\
\cdots \\
\cdots\end{array}$ & $\begin{array}{r}2 \\
\cdots \\
\cdots \\
\cdots \\
\cdots\end{array}$ & $\begin{array}{r}3 \\
\cdots \\
\cdots \\
\cdots \\
\cdots \\
\cdots\end{array}$ & $\begin{array}{r}1 \\
1 \\
1 \\
-\cdots\end{array}$ & 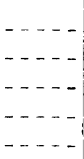 & $\begin{array}{r}7 \\
1 \\
1 \\
---4\end{array}$ \\
\hline 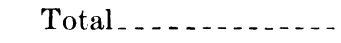 & 49 & $-\cdots-$ & 5 & 4 & 4 & 2 & 3 & 4 & 3 & 3 & 3 & 5 & $-\cdots-$ & 13 \\
\hline Cumulative percent_- & 100.0 & 0 & 10. 2 & 18. 4 & 26.5 & 30.6 & 36.7 & 44. 9 & 51.0 & 57.1 & 63.3 & 73.5 & 73.5 & 100.0 \\
\hline
\end{tabular}

Table 4. Reported cases and deaths from whooping cough and rates, by race, ${ }^{1}$ Florida, $1951-55$

\begin{tabular}{|c|c|c|c|c|c|c|c|c|}
\hline \multirow{3}{*}{ Year } & \multicolumn{2}{|c|}{ Number of cases } & \multicolumn{2}{|c|}{ Number of deaths } & \multicolumn{4}{|c|}{ Rate per 100,000} \\
\hline & \multirow{2}{*}{ White } & \multirow{2}{*}{ Nonwhite } & \multirow{2}{*}{ White } & \multirow{2}{*}{ Nonwhite } & \multicolumn{2}{|c|}{ Cases } & \multicolumn{2}{|c|}{ Deaths } \\
\hline & & & & & White & Nonwhite & White & Nonwhite \\
\hline $\begin{array}{l}1951 \\
1952 \\
1953 \\
1954\end{array}$ & $\begin{array}{l}663 \\
158 \\
153 \\
289 \\
839\end{array}$ & $\begin{array}{r}244 \\
129 \\
54 \\
44 \\
239\end{array}$ & $\begin{array}{l}6 \\
1 \\
1 \\
1 \\
1\end{array}$ & $\begin{array}{r}21 \\
4 \\
3 \\
-11 \\
11\end{array}$ & $\begin{array}{r}29.0 \\
6.6 \\
6.2 \\
10.3 \\
28.7\end{array}$ & $\begin{array}{r}39.5 \\
20.5 \\
8.5 \\
6.4 \\
33.0\end{array}$ & $\begin{array}{l}0.3 \\
(2) \\
(2) \\
(2) \\
(2)\end{array}$ & $\begin{array}{r}3.4 \\
.6 \\
.5 \\
1.5\end{array}$ \\
\hline Average ....... & 420 & 142 & 2 & 8 & 17.0 & 22.3 & 0.1 & 1.2 \\
\hline
\end{tabular}

${ }^{1}$ Cases with race unknown are excluded.

${ }^{2}$ Rate less than 0.1 .

treatment after diagnosis in the early stages of the disease.

Typical case histories, supplied by Dr. James Stem, Dr. B. M. McKlosky, and Dr. Felix Balmir, follow :

CASE 1: N. W., a 16-month-old white female infant, was 1 of 6 siblings. The public health nurse had been in frequent contact with the family, but their religious beliefs had prevented immunization. Twenty-three days prior to death, the child developed a mild upper respiratory disease. Although typical cases of whooping cough were present in the older siblings, medical attention for the child was not obtained until 3 days prior to death. Severe paroxysm with typical whoop had been present for 5 days, and on the day of admission to the hospital, the child had been in a continuous convulsion for 4 hours with a temperature of $105^{\circ} \mathrm{F}$. The total white cell count on admission was 21,000 with 71 percent lymphocytes. The hemoglobin was 11.8 grams. Despite administration of chloramphenicol and penicillin intramuscularly, adrenal cortical ex- tract intravenously, continuous oxygen, and standard anticonvulsant therapy, the child remained comatose and died on the second day in the hospital.

CASE 2: E. C., a 1-month-old Negro female infant, became ill 14 days before death. Two other siblings in the home were apparently well. The mother did not recall having had whooping cough in her childhood. The initial symptoms were infrequent spells of coughing associated with collection of mucus. On the $3 \mathrm{~d}$ and 10 th day of the illness, a physician saw the child and prescribed Achromycin (tetracycline). Four days before death, the coughing became paroxysmal. The child became febrile and developed respiratory distress. While nursing on the final day of life, the child was seized by a paroxysm of coughing and died.

Case 3: E. M. C., a 10-month-old Negro female infant, had onset of a mild respiratory illness 14 days before death. No family or neighborhood contact had whooping cough. At age 5 months she had visited the local health department clinic for immunization, but the parents were told to return her 
at 6 months of age for her initial immunization. In the second week of her illness she developed typical coughing with inspiratory whoop, having 12 to 20 paroxysms per day. These were said to be accompanied frequently by convulsive episodes. On the 13th day of her illness, she was admitted to the hospital. Temperature on admission was $105^{\circ}$ F. The white cell blood count was 22,850 with 67 percent lymphocytes. A chest X-ray revealed findings consistent with a diagnosis of interstitial pneumonia. She received intramuscular penicillin, streptomycin, and 2.5 cc. of pertussis hyperimmune serum. Despite heroic therapeutic measures, she died on the second day in the hospital.

\section{Discussion}

The first case represents the frustration of the best of medical and public health facilities by the lack of intelligent interest on the part of parents. The second case presents a typical problem in diagnosing a small infant. Pneumonia, perhaps due to aspiration, was the initial diagnostic impression, but in retrospect an underlying infection with $H$. pertussis was considered the most likely cause of death. It is a moot question whether, if this were the actual cause and it had been diagnosed, treatment would have altered the outcome of the case. Case 3 illustrates the need for beginning pertussis immunization at an earlier age than 6 months. In only 2 of the 12 cases was there a record of any prior pertussis immunization, and these were single diphtheria-pertussistetanus injections. In one case the health department notice reminding the parents of the need for immunization arrived the day after the death of the child. In two instances the parents refused immunization, in one they were unaware of the need, and in four cases immunization was deferred until the infant reached an older age.

It is generally agreed that immunization is the major weapon against whooping cough, and it would appear that in Florida it needs more vigorous use. The cyclical occurrence of the disease indicates a periodic buildup of susceptibles due to new births, although immigration cannot be ignored as a possible contributory factor in Florida. Particular interest needs to be centered on giving complete immunization to the group of children under 6 months of age. The American Academy of Pediatrics (3) recommends beginning pertussis immunization whether alone or in combination with diphtheria and tetanus between the second and fourth months of life. It has been shown that infants of this age are capable of producing agglutination antibodies against pertussis, although the response is quantitatively not as good as that against diphtheria and tetanus toxoids $(4,5)$.

There is a need in Florida for extending the immunization of Negro infants, a challenge of particular urgency for public health physicians. Private physicians should continue to stress the importance of immunizations as a part of the routine of infant care. It would appear important also to consider possible whooping cough in all protracted upper respiratory illnesses of infants with or without the typical inspiratory whoop. Parent education on the importance of routine medical attention for young infants is the job of all who are concerned about the future health and welfare of our children.

\section{Conclusions and Summary}

Whooping cough remains a major cause of death in infants in the communicable disease category. In Florida a reduction of the case rate by 56 percent during the period 1948-55 would seem to be related in time to the introduction and use of pertussis vaccine and antibiotic therapy. Modesty is appropriate, however, in assessing these therapeutic efforts since the steadily declining mortality rates are unrelated in time to specific preventive or therapeutic measures.

The epidemic year 1955 is ascribed to inadequate immunization of young children, particularly those under 6 months of age.

Routine pertussis immunization of infants beginning at the second month of life is necessary for complete control of this disease.

\section{REFERENCES}

(1) Treatment of whooping cough with antibiotics. A report by the Whooping Cough Sub-Committee of the Antibiotics Clinical Trials (non-tuberculous conditions) Committee of the Medical Research Council. Lancet 264: 1109-1112, June 6, 1953. 
(2) Ames, R. G., and others: Comparison of the therapeutic efficacy of four agents in pertussis. Pediatrics 11 : 323-337, April 1953.

(3) American Academy of Pediatrics: Report of Committee on Infectious Disease. Evanston, Ill., 1955.

(4) Felton, H. M., and Verwey, W. F.: The epidemio- logical evaluation of a non-cellular pertussis antigen. Pediatrics 16:637-651, November 1955.

(5) Di Sant' Agnese, P. A.: Combined immunization arainst diphtheria, tetanus and rertussis in new born infants. Pediatrics 3: 20-33, January 1949.

\section{publications}

\section{Special Health Services}

PHS Publication No. 530. 195\%. 19 pages; illustrated.

Activities concerned with accident prevention, air pollution, chronic disease, the aged, heart disease, occupational health, radiations, and tuberculosis are described in popular language, with glimpses of the work of the Division of Special Health Services of the Bureau of State Services, Public Health Service.

\section{Tuberculosis Chart Series 1957}

PHS Publication No. 534. 195\%. 45 pages; charts.

This edition charts comprehensively the statistical aspects of the tuberculosis problem in the United States. The facts and figures, derived from many authoritative sources, cover a wide range of problems and challenges and are designed to provide a sound basis for program planning. Some of the subjects included are: estimated prevalence of cases ; major types of expenditures, 1952 and 1956 ; newly reported cases and deaths, 1930-56; age-specific rates for newly reported active cases and deaths, 1955 ; race and sex of fatalities and newly reported active cases, 1955 ; and newly reported active cases per 100,000 population, United States and Territories, 1956.
Many of the charts, published formerly in the chart series, are reprinted because of their continuing pertinency and interest. Additional charts will be published in subsequent editions as new problems arise and changing trends demand.

\section{Proceedings, 1956 Annual Conferences}

Surgeon General, Public Health Service, and Chief, Children's Bureau with State and Territorial health officials

PHS Publication No. 522. 195\%. 54 pages.

The proceedings contain the deliberations of the 1956 conferences of the Surgeon General with State and Territorial health officials, hospital and medical facilities survey and construction authorities, and mental health authorities. Addresses made to each of these groups are part of the publication.

Recommendations and resolutions of the participating State and Territorial officials reflect the attention given to such subjects as chronic illness and aging and standards for hospital and nursing home care ; reporting of vital records and statistical data; accidents, labeling laws and regulations, and poison information centers ; civil defense, radiological defense, and other emergency measures; curriculums for professional schools, training of dental and other public health personnel, and training of mental health personnel for community services; water and air pollution, Indian health, migratory labor, and other public health problems.

\section{VD Fact Sheet}

PHS Publication No. 341. Issue No. 13. 1956. 22 pages; tables.

Intended as a ready source of basic statistics on the venereal diseases in the United States, this publication presents data on trends in venereal disease incidence and prevalence. Other statistics relate to the estimated annual costs of uncontrolled syphilis, mortality and insanity due to syphilis, reported cases of venereal diseases, case-finding activities, morbidity by age, congenital syphilis, and use of penicillin in treatment of syphilis.

The information, current as of December 1956, supersedes previously published data.

This section carries announcements of all new Public Health Service publications and of selected new publications on health topics prepared by other Federal Government agencies.

Publications for which prices are quoted are for sale by the Superintendent of Documents, U. S. Government Printing Office, Washington 25, D. C. Orders should be accompanied by cash, check, or money order and should fully identify the publication. Public Health Service publications which do not carry price quotations, as well as single sample copies of those for which prices are shown, can be obtained without charge from the Public Inquiries Branch, Public Health Service, Washington 25, D. C.

The Public Health Service does not supply publications issued by other agencies. 